John Carroll University

Carroll Collected

History

$12-1997$

\title{
Challenging Political Culture in Postwar Austria: Veterans Associations, Identity, and the Problem of Contemporary History
}

Matthew P. Berg

John Carroll University, mberg@jcu.edu

Follow this and additional works at: http:// collected.jcu.edu/hist-facpub

Part of the History Commons

\section{Recommended Citation}

Berg, Matthew P., "Challenging Political Culture in Postwar Austria: Veterans' Associations, Identity, and the Problem of Contemporary History" (1997). History. 14.

http://collected.jcu.edu/hist-facpub/14

This Article is brought to you for free and open access by Carroll Collected. It has been accepted for inclusion in History by an authorized administrator of Carroll Collected. For more information, please contact connell@jcu.edu. 


\title{
Challenging Political Culture in Postwar Austria: Veterans' Associations, Identity, and the Problem of Contemporary History
}

\author{
Matthew Paul Berg
}

Since the Waldheim election and the almost simultaneous appearance of Jörg Haider, recent history is a permanent guest at the center of politics. ${ }^{1}$

7 HIS observation, registered by Marianne Enigl and Herbert Lackner, points to an incontestable and compelling feature of contemporary Austrian political culture: during the 1980s and 1990s, the first meaningful steps toward an Austrian Vergangenheitsbewältigung developed out of a discussion of Austrians' military service during the Nazi era and its highly problematic association with wartime atrocities and genocide. Exploration of this important theme had been avoided throughout the period of the Second Republic by a carefully cultivated expression of public memory. The inherent tension between the internationally sanctioned notion of Austrian victimization during the Nazi years and the pride of many Austrian veterans in having performed their soldierly duties (Wehrpflichterfüllung) had been a taboo subject. Domestic reactions to the international controversy surrounding Kurt Waldheim's successful 1986 presidential campaign, however, reduced the psychological barriers that had enabled-indeed, encouraged-many Austrians to repress reflections upon their own experiences under the Third Reich, and had largely checked the extent to which the period was subject to critical scrutiny. ${ }^{2}$

This article developed from a paper presented at the Twentieth Annual Conference of the German Studies Association Seattle, 10-13 October 1996. I would like to thank Oliver Rathkolb, Anton Pelinka, and Günter Bischof for their comments and suggestions. Thanks are also due to Pamela Mason for her critical reading of an earlier draft.

1. Marianne Enigl and Herbert Lackner, "Die verschüttete Geschichte," Profil 6 (3 February 1996): 21. All translations are mine, unless otherwise noted.

2. Among the important contributions to a reexamination of this repressed past are Gerhard Botz, "Österreich und die NS-Vergangenheit:Verdrängung, Pflichterfulllung, Geschichtsklitterung" in Ist der Nationalsozialismus Geschichte? Zu Historisierung und Historikerstreit, ed. Dan Diner, (Frankfurt am Main, 1987), 141-52; Siegfried Mattl and Karl Stuhlpfarrer, "Abwehr und Inszenierung im Labyrinth der Zweiten Republik," in NS-Herrschaft in Österreich 1938-1945, ed. Emmerich Tálos, Ernst Hanisch, and Wolfgang Neugebauer (Vienna, 1988), 601-24; Richard 
The difficulties in managing historical memory are evident in the challenging conundrum stemming from Waldheim's military service-or, for that matter, that of any Austrian veteran: how could one take pride in having "done one's duty" in the uniform of the Wehrmacht or SS, yet lay claim to victimization at the hands of the Nazi regime? In Waldheim's case this issue was approached, initially, in the most reticent fashion; once broached, it led to bitter debate. Jörg Haider's statements and symbolic actions, on the other hand, have represented a righteous, defiant proscription of the prevailing, tacit consensus of fifty years that this past was to be minimized, if not ignored outright. Several months before the Waldheim Affair focused closer attention on Austria's past, Haider, a member of the first postwar generation and then-emerging leader of the right-wing Freiheitliche Partei Österreichs (Austrian Freedom Party; hereafter FPÖ), praised former SS members at a veterans' reunion in late 1985, telling them that their sacrifices had saved the Heimat and Western Europe from bolshevism. ${ }^{3}$ Only ten years later, prior to the December 1995 Austrian federal elections, footage of yet another (and clearly not infrequent) Haider appearance before a Waffen SS reunion was broadcast on German television. On this occasion he lauded the veterans as decent men of unimpeachable moral character.

The Waldheim controversy and Haider's carefully chosen, impolitic remarks frame the central theme to be explored in this essay-namely, the place of martial values in a fragile and in some respects ambivalent construction of Austrian identity during the initial postwar years. The Allies' determination not to issue a pronouncement of collective guilt for waging a war of aggression or crimes against humanity, coupled with a then-widely accepted representation of the Wehrmacht as a politically neutral, professional military force, spared most soldiers from prosecution, and many other Austrians the need for uncomfortable introspection. ${ }^{4}$ Austrian veterans and civilians were protected by the Moscow Declaration (1943), reiterated at Yalta two years later, that Austria had been the first victim of German aggression. ${ }^{5}$

Mitten, The Politics of Antisemitic Prejudice: The Waldheim Phenomenon in Austria (Boulder, 1992); Meinrad Ziegler and Waltraud Kannonier-Finster, Österreichs Gedächtnis: Über Erinnern und Vergessen der NS-Vergangenheit (Vienna, 1993); Gerhard Botz and Gerald Sprengnagel, eds., Kontroversen um Österreichs Zeitgeschichte: Verdrängte Vergangenheit, Österreich-Identität, Waldheim und die Historiker (Frankfurt am Main, 1994).

3. Brigitte Bailer-Galanda, Haider wörtlich (Vienna, 1995), 102; cited originally in Kärtner Nachrichten, 13 October 1985.

4. For a survey of the integration of the First Republic's Bundesheer into the Wehrmacht and Austrian participation in the Third Reich's armed forces, see Walter Manoschek and Hans Safrian, "Österreicher in der Wehrmacht," in Tálos, et al., NS-Herrschaft, 331-60. The essay focuses on the war in the Balkan theater.

5. Developed originally as a psychological weapon by British officials and supported by their American counterparts to exploit "anti-Prussian" sentiment within Austria, the Moscow Declaration, Robert Keyserlingk explains, "came to be considered a gauge of Allied wartime intentions"-particularly with the emergence of the Cold War-concerning the restoration of Austria and was integrated into the legal-political basis of the Second Austrian Republic." Keyserlingk, 
The notion of Austrian victimization enshrined in the Moscow Declaration, linked with the Allied rejection of a collective guilt clause for Austria, has been aptly referred to as the "Magna Carta of the Second Republic" and as the source of the Austrian Lebenslïge-i.e., that of collective victimization rather than many troubling instances of individual complicity. ${ }^{7}$ Moreover, it became the basis for a national myth; as Robert Knight points out, it legitimized the myth of victimization. ${ }^{8}$ This formalized expression of public memory, reiterated in 1955 in the State Treaty that ended the occupation of Austria, confirmed the sense of disillusionment which a great many Austrians felt by war's end, and served as a kind of collective exoneration for the years 1938-1945. For the vast majority of former soldiers in particular, the Moscow Declaration facilitated the separation of Nazi-era military service from its association with genocidal conflict. ${ }^{9}$ Moreover, the Opferthese, with its function as an agent for memory repression $^{10}$ came to represent a direct, embarrassing challenge to one of the central questions for postwar identity formation: what role, if any, might martial values play if an inchoate sense of Österreichertum was to be founded upon principles

Austria in World War II: An Anglo-American Dilemma (Kingston, Ontario, 1988), 4. See also Günter Bischof, "Die Instrumentalisierung der Moskauer Erklärung nach dem zweiten Weltkrieg," Zeitgeschichte 20 (1993): 345-66. Bischof's essay is both a thoughtful discussion of how Austrian politicians exploited the notion of victimization, particularly during the 1940 s and 1950 s, and a fine historiographical contribution.

6. Thomas Albrich, “'Es gibt keine jüdische Frage': Zur Aufrechterhaltung des österreichischen Mythos," in Der Umgang mit dem Holocaust: Europa-USA-Israel, ed., Rolf Steininger (Vienna, 1994), $147 f$.

7. See Anton Pelinka and Erika Weinzierl, eds., Das grosse Tabu: Österreichs Umgang mit seiner Vergangenheit (Vienna, 1987), as well as Gerhard Botz, "Geschichte und kollektives Gedächtnis in der Zweiten Republik: 'Opferthese,' 'Lebenslüge' und Geschichtstabu in der Zeitgeschichtsschreibung" in Inventur 45/55: Österreich im ersten Jahrzehnt der Zweiten Republik, ed. Wolfgang Kos and Georg Rigele (Vienna, 1996), 51-85. To place Austrian circumstances regarding the delicate, yet highlycharged matters of denazification, dealing with collaborators, and Vergangenheitsbewältigung in a broader European context, see Dieter Stiefel, Entnazifizierung in Österreich (Vienna, 1981); Sebastian Meissl, Klaus-Dieter Mulley, and Oliver Rathkolb, eds., Verdrängte Schuld, verfehlte Sühne: Entnazifizienung in Österreich (BadVöslau, 1986); Heidemarie Uhl, Zwischen Versöhnung und Verstörung: Eine Kontroverse um Österreichs historische Identität fünfzig Jahre nach dem "Anschluss" (Vienna. 1992); Klaus-Dietmar Henke and Hans Woller, eds., Politische Säuberung in Europa: Die Abrechnung mit Faschismus und Kollaboration nach dem Zweiten Weltkrieg (Munich, 1991); Henry Russo, The Vichy Syndrome: History and Memory in France since 1944 (Cambridge, MA, 1991).

8. Robert Graham Knight, "Besiegt oder befreit? Eine völkerrechtliche Frage historisch betrachtet," in Die bevormundete Nation: Österreich und die Allierten, 1945-1949, ed. Günter Bischof and Josef Leidenfrost (Innsbruck, 1988), 77.

9. The notion of the Austrian soldier-as-viction was underscored in the first parliamentary session of the Second Republic. "Those who had always condemned this [National Socialist] regime and the war," declared Chancellor Leopold Figl (ÖVP), "now return with the stigma of having fought for this regime. We know that during the war each of the Allied powers had already made the distinction between these victims of terror and those who stood behind them, in order to drive them to the front." Figl's speech met with wildly enthusiastic response from Volkspartei, Socialist, and Communist delegates, while the high commanders of the four occupation forces looked benignly from the loges upon the assembly. Sten.Prot.NR,V. G.P., 2nd Session, 21 December 1945, 19.

10. On the repression of memory, see Ziegler and Kannonier-Finster, Österreichs Gedächtnis. 
such as international cooperation, reconciliation between peoples, and permanent neutrality?

\section{Problematizing State Identity in Contemporary Austrian Political Culture}

Well into the mid-1980s, the peculiar dynamic of postwar Austrian political culture had encouraged the sublimation, if not outright repression, of the inherently inconsistent soldier/victim dualism as politically expedient. Political culture, as I employ the concept here, refers to the "grammar" of public discourse, in which the range of the permissible and the taboo is structured according to specific rules, whether openly articulated or tacitly acknowledged. These rules may evolve as conditions change. ${ }^{11}$ Political culture in the Second Republic, I argue, was and still is shaped primarily by three clusters of factors. First, Austria's people, not unlike other Europeans, exhausted by interwar civil conflict and several years of war-induced misery, were convinced that economic prosperity, welfare, and social peace would check the appeal of left or right-wing extremism after 1945. Consequently, they embraced cooperative, consensual strategies for the resolution of pressing social, economic, and political problems associated with reconstruction and recovery. In the Austrian case, however, there was also a widespread recognition that consensus-based solutions would minimize intrusions by Allied occupation authorities into domestic affairs. Second, along with most Central and Eastern European peoples, Austrians experienced a series of rapid transformations of political regimes between 1918 and 1945-including some combination of monarchy, a short-lived republic, an indigenous authoritarian government, National Socialist dictatorship, and occupation. The stability essential to the success of the Austrian Second Republic was contingent not only upon popular acceptance of, but also continued support for, stable democratic institutions and a distinctly Austrian identity, the latter founded on the principle of victimization. This necessitated the population's willingness to accept new forms of civic education and the development of a state consciousness based in part upon the selective appropriation of time-honored Habsburg and First Republic symbols, and, more significantly, the creation of viable new symbols and practices capable of nurturing and sustaining a fragile and as yet uncertain new identity. To a significant extent, the elements of this revised sense of Österreichertum developed in response to external factors-the complex and somewhat contradictory nature of the Allied occupation on the

11. This notion is adapted from Clifford Geertz's assertion that an interpretive theory of culture has the twofold task of discerning "the conceptual structures that inform our subjects' acts, the 'said' of social discourse, and to construct a system of analysis in whose terms what is generic to those structures, what belongs to them because they are what they are, will stand out against the other determinants of human behavior." Geertz, The Interpretation of Cultures, (New York, 1973), 27. 
one hand, and the popular desire of most Austrians to distance themselves from the trappings of a greater German Volksgemeinschaft, on the other-rather than from a militantly self-conscious, widespread Austrian particularism that had been violently suppressed by the Nazi regime. ${ }^{12}$ Third, as intimated in the Enigl/Lackner quotation, an unspoken agreement not to address past conflict (the resentments and anger stemming from the civil war atmosphere of 1918-1934; the Catholic conservative Austrofascist regime of 1934-1938; and the generally passive acceptance of the National Socialist dictatorship, or instances of active complicity in its repressive and genocidal measures) effectively precluded genuinely critical attempts to come to terms with it. To accept this distancing of society from the past was to preserve the Austrian Lebenslüge against critical revisionists.

The social democratic parliamentarian Peter Kostelka remarked recently that "Austria's political culture distinguishes itself through an inability to engage in conflict." 13 Taking the point a step further, I suggest that postwar, consensus-oriented Austrian political culture has promoted the displacement of the essential content of debate over Austrian identity into the cultural realm. More specifically, formal institutions such as governmental coalitions forged by the Sozialistische Partei Österreichs (Austrian Socialist Party; hereafter SPÖ) and Catholic-conservative Österreichische Volkspartei (Austrian People's Party; hereafter ÖVP) camps (1945-1966 and 1986-present), and the informal "social partnership" of SPÖ labor and ÖVP business and agricultural interests (1945-present) created parameters within which social conflict can be managed-preempting the sorts of bitter conflict over justice in the workplace and constitutional issues that had debilitated the interwar republic. Contestation of incipient identity in the Second Republic, then, was sublimated into areas in which successful negotiation was far from a foregone conclusion-i.e., into the venues of cultural and social reproduction. One finds it manifested at a number of sites: the choice/interpretation of classic German dramatic and musical works at the Viennese Burgtheater,Volkstheater, or the various Festwochen; lobbying for the protection of cultural autonomy for German-speaking minorities in South Tyrol; the content of historical education for primary and sec-

12. Pro-Anschluss sentiment had existed since the end of the monarchy, however, and in the case of the German National camp from as early as the late nineteenth century. On Anschluss thought prior to the Nazi takeover see Helmut Konrad, ed., Sozialdemokratie und "Anschluss": HistorischeWurzeln des Anschlusses 1918 und 1938 (Vienna, 1978) and Stanley Suval, The Anschluss Question in the Weimar Era: A Study of Nationalism in Germany and Austria, 1918-1932 (Baltimore, 1974).

13. Peter Kostelka "Schulterschluss unerwünscht," Wiener Journal 189 (June 1996): 10. This point was made in conjunction with an evaluation of Austro-German relations in the mid-1990s. Although he was at least as concemed with the pervasive problem of contemporary Austrian-style parliamentary gridlock as with skirting around the morass of highly-charged historical memory, Kostelka's comment corroborates the notion that petty disputes have become a substitute for substantive debate over issues which might compel one to discuss issues related to a volatile past. 
ondary school students; the role of the Roman Catholic Church in religious and public education, and its influence upon abortion legislation. These examples, case studies into the nexus between the realms of politics and culture in their own right, suggest the engagement of a variety of institutions with the politics of identity.

This essay takes into consideration a rather different locus in the politics of Austrian identity formation - that of Austrian Second World War veterans and their ambiguous notion of community during the 1950s. I do not contend, thereby, that the potential for a revived militarism or German-national sentiment has been deeply rooted or widespread in the Second Republic. Rather, I argue that the Soldatenverbände and Soldatentreffen (veterans' associations and veterans'reunions, respectively) represented an embarrasment and grounds for concern for those officials determined to nurture an embryonic, still-indeterminate sense of Austrianness in the 1950s. With each ritual celebration of camaraderie, participants in veterans' organizations sought to reestablish an exclusive sense of Gemeinschaft that reaffirmed their identity as former soldiers of the Third Reich. In the process, Kameradschaftsbündler created a troublesome victim/perpetrator dualism for those entrusted with building a credible post-Nazi Austrian community.

A comprehensive history of Austrian veterans has yet to be written. This study seeks to consolidate and advance the small body of literature on veterans' activities, and to explore the contradiction they posed to the fundamental leitmotif of Austrian political culture: the official myth of victimhood. Thus, I am at least as interested in official Austrian reaction to veterans' activities, as it worked to contain them, as I am in the veterans' associations themselves. Included here is a discussion of the Fronterlebnis in World War I and theoretical reflections upon its significance for community-building between 1914 and 1918 , as well as upon the sanctification of this experience during the Third Reich. The body of the essay is an exploration of the enduring importance of the Frontgemeinschaft for organized, right-wing veterans after 1945 and efforts by Austrian authorities and particularly the Austrian Left to check their influence. Contemporary historians should take note that archival source material that had been generated by Kameradschaftsbünde themselves is likely to remain frustratingly incomplete. During the 1950s, veterans associations expressed their views far more frequently through ritual practice than in written form. Newspaper editorials represented the principal exception which survives into the present; veterans' associations newsletters and magazines from the period were subject to strict censorship by Austrian and Allied Control Commission authorities. The most consistent and informative primary sources for Kameradschaftsbund selfexpression come from two sources: first, Interior Ministry reports on the constitution of groups and the nature of their activities forwarded to Vienna by provincial police officials; and second, the statements of right-wing (and even 
ÖVP) member-champions of Kameradschaftsbünde sitting in high-profile public forums such as the Nationalrat. ${ }^{14}$

\section{Theoretical Reflections on Comradeship During the Two World Wars}

The phenomenon of veterans' associations and the commemoration of the dead after the Second World War, particularly with respect to Austria, have only just begun to attract scholarly attention. ${ }^{15} \mathrm{~A}$ considerably larger body of historical scholarship has concerned itself with the cultural history of the First World War experience, and this literature raises questions and themes which can inform reflection upon veterans after $1945 .{ }^{16}$ Among the latter, Eric Leed's now-classic work, informed by Victor Turner's theory of symbols and social structure, offers a most compelling point of departure for the study of the soldier's experience as a complex of rituals involving separation, liminality, and aggregation. This approach is particularly instructive when brought to bear upon the ambiguous nature of commemoration of World War II service on the part of Austrian Kameradschaftsbünde and its relationship to post-1945 identity formation.

Modris Eksteins has argued with respect to the First World War that the indissoluble connection which men forged in combat

... was ... not all that resilient outside of the battle zone when men were forced to confront the complexities of the "real" world. The intensity of feeling and companionship belonged to a similar time and place. That explains why some soldiers were keen to get back to the trenches, from leave and from rest quarters. ${ }^{17}$

14. The latter source is a particularly informative one. FPÖ parliamentary representatives (a great number of them had been Nazis, and were denied their political liberty until 1949), as officials freely-elected by a decriminalized constituency, sought to impart an air of legitimacy to Kameradschaftsbund membership that conflicted with the governing parties' attempts to sweep them under the rug - lest the occupation forces (particularly the USSR and France) find grounds to reexamine the validity of the Austrian Opferthese.

15. For the Austrian case see Reinhold Gärtner and Sieglinde Rosenberger, Kriegerdenkmäler (Innsbruck, 1991); Stefan Riesenfellner and Heidemarie Uhl, eds., Todeszeichen: Zeitgeschichtliche Denkmalkultur in Graz und in der Steiermark vom Ende des 19. Jahrhunderts bis zur Gegenwart (Vienna, 1994); Heidemarie Uhl, "Erinnerung alsVersöhnung: Zur Denkmalkultur und Geschichtspolitik der Zweiten Republik," Zeitgeschichte 23 (1996): 146-60. A more comprehensive European study is George L. Mosse, Fallen Soldiers: Reshaping the Memory of the World Wars (Oxford, 1990). On the politics of veterans' associations as interest group lobbies within the sphere of social welfare policy, see James M. Diehl, The Thanks of the Fatherland: German Veterans after the Second World War (Chapel Hill, 1993).

16. See, for example, Eric J. Leed, No Man's Land: Combat and Identi!y in World War I (Cambridge, 1979); Modris Eksteins, Rites of Spring: The Great War and the Birth of the Modern Age (New York, 1989); Robert W. Whalen, Bitter Wounds: German Victims of the Great War, 1914-1939 (Ithaca, 1984); Jay Winter, Sites of Memory, Sites of Mourning:The Great War in European Cultural History (Cambridge, 1995).

17. Eksteins, Rites of Spring, 232. 
This sentiment, Leed suggests, was the result of habituation to aggression through the experience of combat, a cohesion born of cohabitation of a liminal state in which customary, civilian mores were abrogated. ${ }^{18}$ The resultant behavior was marked by "radical discontinuity on every level of consciousness," and characterized by actions that are taboo in a conventional social structure. Turner's concept of liminality, situated within the framework of religious ritual, focuses upon the novice's separateness from the ordinary structures of "conventionally" constituted society-i.e., the person in a liminal state, on the threshold between two disparate realities, participates in an extra-ordinary transitional community. ${ }^{19}$ Leed argues that the soldier's experience, from his initial military training through his life under combat conditions, is characterized by a profound form of separation from his former, normative community, followed by aggregation into an existential communitas in which the individual's previous social status is transcended:

The experience of living outside of class as a declassified, or not-yet-classified, individual was productive of a sense of comradeship among those who shared this situation. The lack of status of the frontsoldiery, like the statuslessness of a liminal group, can seem to be both a painful loss of identity and a positive liberation from those social distinctions which customarily prevent the formation of close personal bonds across class lines. In going to war the soldier was stripped of the visible marks of status-clothes, address, property, insignia of social rank - that defined his place in society. The formal equality of the army was not, however, comradeship, as many young middle-class volunteers found out. Comradeship came only after the invisible marks of status-attitudes, education, ways of speaking and other manners-were erased ... ${ }^{20}$

Such a process, then, would account for the sense of disassociation, even discomfort, that Eksteins notes many World War I combat troops tended to feel during temporary (re)aggregation into conventional society on leave or on rare visits home without having been formally discharged from their particular liminal state-i.e., the comradeship of the front, either in the east or the west. In Germany and to some extent in Austria as well, the solidarity of this "community on the threshold" between life and death found expression in the Frontkämpfer tradition, in the Kampfgemeinschaft of those who had been through

18. Leed, No Man's Land, 3, 8ff.

19. Turner, The Ritual Process: Structure and Anti-Structure (Ithaca, 1991 [originally 1969]), 94-103 and $127-40$, particularly 132 . Within this liminal, or transitional phase, the fellowship of neophytes results in the creation of a special, temporary community at the margins of normative society, referred to by Turner as existential communitas; idem, Dramas, Fields, and Metaphors: Symbolic Action in Human Society (Ithac2, 1994 [originally 1974]), 169.

20. Leed, No Man's Land, 25. 
the experience of conflict shaped by the unprecedented destructive power of the period's advanced weaponry. ${ }^{21}$

\section{Frontkämpfer and Frontgemeinschaft}

In the particular case of World War II, the formation of a front-soldier identity was linked to the heroically-depicted myth of the Fronterlebnis of 1914-1918 cultivated by veterans, as well as to the respect for the myth inculcated in youth during the 1930s and early 1940s. In the case of the armed forces themselves, an outright emphasis upon "the myth of the so-called Frontgemeinschaft of 1914-1918," explains Omer Bartov, with "the related belief that only total spiritual commitment would enable one to withstand, if not actually celebrate, the horrors of modern war ..." linked members of the Wehrmacht to veterans of the Great War, and contributed forcefully to a sense of soldierly community in the Wehrmacht. ${ }^{22}$ Solidarity intrinsic to the concept of Gemeinschaft, born out of the quasi-sacral experience of warfare as a sanctified state, would promote a very high degree of unit cohesion in the armed forces of the Third Reich ${ }^{23}$ and would foster the strong postwar ties among many veterans which translated into the formation of veterans' associations.

In his discussion of the socialization of boys through the Hitler Youth into a militant "rebellious conformism," Bartov notes that their education "did not make them all into committed Nazis." He suggests most convincingly that this upbringing, nonetheless, "provided them with an outlook that profoundly influenced their manner of both physically and mentally coping with and reacting to the realities of the war [...] whether or not they happened to be enamored of the regime." ${ }^{24}$ Bartov's point is substantiated by work on the Hitler Youth $(\mathrm{HJ})$ that has underscored the value the regime placed upon the martial training and Nazi Staatsbürgerkunde to which boys were subjected in

21. The new experience of combat as a product of new weaponry is too large a topic to address here, but a fine corpus of scholarly work has been devoted to the subject. See, for example, John Ellis, Eye-Deep in Hell: Trench Warfare in World War I (Baltimore, 1976); Denis Winter, Death's Men: Soldiers of the Great War (Harmondsworth, 1979); Eksteins, Rites of Spring; Bernd Ulrich and Benjamin Ziemann, eds., Frontalltag im Ersten Weltkrieg:Wahn und Wirklichkeit (Frankfurt am Main, 1994).

22. Omer Bartov, Hitlers Army: Soldiers, Nazis, and War in the Third Reich (Oxford, 1992), 60. My emphasis. See also Diehl, The Thanks of the Fatherland, 45f and Stephen G. Fritz, Frontsoldaten:The German Soldier in World War II (Lexington, KY, 1995), 188-90, 207-8, 217-18.

23. On the issue of solidarity see also Edward A. Shils and Morris Janowitz, "Cohesion and Disintegration in the Wehrmacht in World War II," Public Opinion Quarterly 12 (1948): 280-309.This classic essay, the best of early work on the source of the Wehrmacht's internal strength as well as its limits, advances a version of the "rational actor" model of individual and group behavior. While persuasive in many respects, it fails to develop sufficiently the importance of the central concept of comradeliness, without which the Frontgemeinschaft could not have existed. Solidarity, I suggest, cannot be easily accounted for in a rational-choice influenced approach.

24. Omer Bartov, "The Conduct of War: Soldiers and the Barbarization of Warfare," Journal of Modern History 64 (Supplement, 1992): 42. 
their formal capacity as $\mathrm{HJ}$ members and in the course of their schooling. $\mathrm{HJ}$ participation had become mandatory for all German - and Austrian - boys by the time of the invasion of Poland in September 1939, and served, indeed, as a viable institution through which to cultivate a Nazi interpretation of soldierly virtues. Wehrmacht and SS recruiters competed actively against one another to attract the elite among late teenaged Hitler Youth members; by 1942 Wehrertüchtigungslager der Hitler-Jugend provided a forum in which boys between sixteen and eighteen spent three weeks, under the tutelage of SS, army, and air force trainers, engaged in intensive exercises and drills intended to develop character, military readiness, and combat capabilities. The trainers drew upon the boys' previous ten years' regimen of physical education as a basis for this premilitary training. ${ }^{25}$ This emphasis upon preparing boys physically for the regime's conception of a Manichaean struggle for living space and racial mastery was complemented, of course, by a thorough nazification of historical and biological education, the class barrier-breaking potential of Labor Service, and the virtual deification of Hitler as the omniscient and omnipotent Führer. All contributed to a climate in which boys were likely to accept the general features (at the very least) of the Nazi ideal of the Volksgemeinschaft-as-Kampfgemeinschaft once they entered the Wehrmacht or the Waffen-SS.

According to Turner, the "neophyte in liminality must be a tabula rasa [. . . ] on which is inscribed the wisdom of the group, in those respects that pertain to new status."26 Given the hallowed character attributed to conflict in the service of National Socialism as inculcated through the teaching of history, popular propaganda, and military training, the front line soldier's experience of combat may have been less the inscription of a sacred mystery upon a naive neophyte, and more the confirmation of what passed for self-evident truth imparted through earlier socialization. Because the war against the Soviet Union was cast as a racial crusade, an ideological war against an inferior, subhuman enemy (consider the infamous "Commissar Order"), wanton or excessive violence directed toward civilians, Soviet POWs, and particularly Jews rarely met with punishment, and was, rather, all too frequently encouraged.

Regardless of the symbolic capital in which the neophyte invested, whether or not a soldier considered himself a $\mathrm{Nazi}$, an inveterate nationalist, or merely a

25. See, in particular, Gerhard Rempel, Hitler's Children:The Hitler Youth and the SS (Chapel Hill, 1989), 173-204, esp. 184, and Peter D. Stachura, "Das Dritte Reich und die Jugenderziehung: Die Rolle der Hitlerjugend 1933-1939," in Nationalsozialistische Diktatur 1933-1945: Eine Bilanz, ed. Karl Dietrich Bracher, Manfred Funke, and Hans-Adolf Jacobsen (Bonn, 1986), 224-44. "To serve a Volksgemeinschaft, to live a life of camaraderie, to believe in the German people and Hitler as the German Führer," explains Stephen Fritz, "these were ideals pressed into the minds and souls of German youth." Fritz, Frontsoldaten, 161.

26. Turner, The Ritual Process, 103. 
defender of the Reich, ${ }^{27}$ the conclusion one might draw from the scholarship discussed above is that combat experience either fostered or reinforced a sense of Front- or Kampfgemeinschaft during the Second World War comparable to that of the 1914-1918 experience, but shaped by the even more highly-charged, extraordinary circumstances of a war of annihilation. The experience of the Frontgemeinschaft was such a profound one that the individual veteran could, as Leed has argued with respect to the World War I ex-serviceman, identify with the "rites and symbols" of the war years as a commemoration, even continued celebration of liminality, without necessarily supporting National Socialist or, later, Neo-Nazi principles. ${ }^{28}$ What follows is a discussion of veterans' groups as an expression of what Turner refers to as normative communitas-the creation of a structured community through which a group that experienced a common, transformative experience attempts "to preserve, in and by its religious and ethical codes and legal and political regulations" the original experience of fraternal Gemeinschaft. ${ }^{29}$ Juxtaposed with the emergence of Kameradschaftsbünde is an examination of the Austrian authorities' attempts to monitor and contain them during the 1950s-a period during which the official Austrian state identity based on victimization began to gain wider currency, and in which veterans' groups began to proliferate with the reenfranchisement of many former Nazis.

\section{Commemoration of Comradeship in the Second Republic: The Occupation Years}

Between the years 1914 and 1945, virtually all Germans and Austrians had themselves, or had seen a friend or relative, become a member of the imperial armed forces, a paramilitary formation, and/or a branch of the Third Reich's military machine. The experience of formal combat service ended when the National Socialist regime capitulated in the spring of 1945, yet the liminal character of frontline solidarity transformed itself, for some, in the politicization of this experience after the war's end. The implications of this feeling of solidarity, the result of having existed on the threshold between youth and adulthood, life and death, one's status as a kind of crusader and one's reintegration into a defeated and often vilified social body, had important ramifications for the stability of fledgling postwar Austrian and German societies. George L. Mosse has

27. "We were never mercenaries, but-to use the hackneyed phrase-defenders of the Fatherland.There are certainly those among our ranks who fight for the idea of National Socialism, and others who fight for the fatherland, that spot on the map for which risking one's life remains self-evident. We lie together in the tent." This statement, authored by the young Landser Egon Freitag in August 1941, is a representative example of the fine line between comradeship and the contours of Nazi weltanschauung, and in other cases the linkage between them. Cited in Bartov, Hitler's Army, 34.

28. Leed, No Man's Land, 33.

29. Turner, Dramas, Fields, and Metaphors, 169; Turner, The Ritual Process, 132. 
remarked that former soldiers of the Third Reich frequently found that the "idea of self-sacrifice [was] motivated by a feeling of solidarity moved to the foreground [i.e.,] loyalty to individual fellow soldiers rather than to any overriding purpose." ${ }^{30}$ Among a population exhausted by war and suffering total defeat, groups of former SS and even Wehrmacht members attempted to revive what Mosse has designated "the Myth of the War Experience"-the tendency to reflect upon battle as a formative, even sanctified experience, and to influence collective memory to this end through the promotion of literary works and popular publications, film, posters, bric-a-brac, and membership associations. ${ }^{31}$ Veterans who glorified their wartime existence through formal organization did not likely comprise an overwhelming majority of former servicemen. Nonetheless, the fact that such veterans could not find a fundamental sense of Gemeinschaft (outside that of the Fronterlebnis) capable of transcending what they regarded as the limiting structures of everyday civilian life once the war ended was a cause of concern for the authorities in postwar German and Austrian societies.

All in all, the transition from the Frontgemeinschaft, where warfare had represented the fundamental rite of passage in the National Socialist constellation of values, to civilian life in Germany and Austria proved itself to be a rather successful process. Paramilitary violence was never a reality after 1945; social welfare benefits were extended to veterans and returning POWs to ease their transition; Red Cross, United Nations, and other international funding sources, as well as Marshall Plan monies, helped provide the basic necessities and capital for reconstruction in Western Germany and Austria, and the occupation authorities effectively monopolized the use of force.Veterans' associations, with their reverence for notions of duty and service designated as anathema after the capitulation, however, embodied a celebration/commemoration of a marginalized community that threatened both the newly-constituted legal order and, in the Austrian case, the myth of victimization.

In the two Germanys the occupation authorities were naturally suspicious of veterans' unauthorized activities, as were state and federal authorities. Circumstances in Austria were somewhat more complicated. The Allied Control Commission and federal and provincial officials shared the same concerns as their German counterparts for the democratic and antimilitaristic development of their populations, but in Austria those in positions of responsibility, as well as ordinary citizens, found themselves on the horns of a uniquely Austrian dilemma. On the one hand, many people from across the political spectrum had

30. Mosse, Fallen Soldiers, 217. West German popular film and literature of the 1950s, Mosse points out, "pictured German soldiers, officers in particular, as decent men of honor who were not to blame for the crimes of Hitler or the loss of the war. Such decency, now central to the ideal of camaraderie, was a counterweight to a war fought in a bad cause."

31. Ibid., 7ff. 
fought in the war, and, even if not confirmed Nazis, believed that they had done their duty. "Duty to whom?" and "Duty to what end?" are, as noted, two questions which those who would glorify the Frontkämpfer experience avoided studiously. ${ }^{32}$ Rather than acknowledge that such sentiment competed with, and endangered the credibility of, the official, carefully nurtured myth of Austria-asfirst-victim, advocates of a revived "Myth of the War Experience" attempted to exonerate Austrians-those who fought in a German war of conquest and also those who supported the regime on the home front-by lumping civilians and soldiers together as victims of "bombs, misery, hunger, need, and the Russians." 33 On the other hand, a vocal minority, largely but not exclusively composed of Socialists and Communists, demanded that the experiences of the National Socialist era be rejected and the symbols and trappings of the period be eliminated.

The first elected government of Austria's Second Republic took quick action against the exhibition of Third Reich military symbols, working with parliament to enact legislation that outlawed the wearing of Wehrmacht uniforms. ${ }^{34}$ Wearing the uniform or insignia of any SS branch had been prohibited as a consequence of the Provisional Government's sweeping measure outlawing the NSDAP within Austria in early May $1945 .{ }^{35}$ The law did not stipulate, however, that prevention of public display of official Nazi-era dress would be coupled

32. "When fulfillment of duty is spoken of in connection with combat action for the NSRegime, it would be appropriate to rethink the notion of 'duty' in this context. If instead of 'duty,' 'compulsion' were employed, then an understanding of the activities of German Wehrmacht soldiers would be more easily possible, then the self-imposed justificatory ideal of former soldiers of the NS-Regime of this kind would no longer be necessary either." In Gärtner and Rosenberger, Kriegerdenkmäler, 94. See also Heidemarie Uhl's content analysis of several recent articles written by Ingomar Pust in the Carinthian ÖVP's Neue Volkszeitung. Pust lamented the fate of the civil population in fire-bombed Dresden (17 February 1988) and the heroic German army at Stalingrad (30 January 1988), and justified brutal action on the part of the Wehrmacht against the "Tito-Partisans" (whom he lumped together with Slovenian resistance fighters) and Communists in the Balkans (13 and 18 February 1988) in Uhl, Zwischen Versöhnung und Verstörung, 388-89.

33. ,139. Uhl spares no criticism for those who appropriated the late Andreas Hillgruber's argument in order to advance that Austrians, like the Germans, had defended "Volk und Vaterland" against murder, rape, plunder, and dislocation (ibid., 138). See also Hillgruber, Zweierlei Untergang: Die Zerschlagung des Deutschen Reiches und das Ende des europäischen Judentums (Berlin, 1986), as well as $\mathrm{Z}$ iegler and Kanonnier-Finster. The authors' case studies provide analyses of the self-representations of average Austrians whose experiences as soldiers, police officers, or civilians had led them to conclude that they had been victims-consistent with the notion of the Moscow Declaration-asMagna Carta on the one hand, or agent of memory repression on the other.

34. ÖStA/AdR, BKA 40.141-2/46. Parliamentary deputies approved the Uniform-Verbotsgesetz on 21 December 1945, not quite one full month after the Second Republic's first democratic elections; it went into effect on 15 January 1946 as BGB1. 1945/12. Punishment for conviction carried a fine of up to ÖS 2,000 or a prison stay as long as two months. The law was not enforced consistently across provincial borders, or even within the same province.

35. Gertrude Enderle-Burcel, Rudolf Jerábek, and Leopold Kammerhofer, eds., Protokolle des Kabinettsrates der Provisorischen Regierung Karl Renner 1945, vol. 1: 29. April bis 10. Juli 1945 (Vienna, 1995), 30-34. This section of the text refers to the discussion of StGB1. 1945/13, 13 May 1945. See also Stiefel, Entnazifizierung, 81-88. 
with forced expiation for deeds the wearer may have committed while clothed in it-nor did it stipulate that some form of civic atonement was necessary for having "done one's duty" in the service of a "foreign" armed force. Problems stemming from the literal superficiality of this legislation manifested themselves particularly from 1949 into the early 1950s. This period marked the first of two surges of Austrian Kameradschaftsbund formation. While veterans' associations did exist prior to 1949, their number was negligible and their activities understated; their gatherings were not regarded as an embarrassment by Austrian officials or the occupation authorities, for they tended to avoid celebration of the ideologically-charged Frontgemeinschaft, and their members were not among those designated as Nazis according to the terms of denazification legislation ratified during the immediate postwar years. ${ }^{36}$ The number of Kameradschaftsbünde proliferated and the politically suspect character of their self-conception changed after 1948, when large numbers of former Nazis judged to be less incriminated (minderbelastet, as opposed to those designated belastet) were permitted full participation in civic life, including the right to form associations. ${ }^{37}$ In Styria, the provincial Kameradschaftsbund association numbered 300 locally-registered organizations with some 60,000 members in $1952 .{ }^{38}$ In the province of Salzburg, one of the less densely populated Austrian Bundesländer, federal police authorities counted 64 registered groups with several thousand members by 1956. Their charters reveal that among them were associations dedicated to comradeship broadly defined (i.e., nonveterans were permitted to become members), to nurturing and sustaining friendship between veterans specifically, and to shooting clubs. ${ }^{39}$

The stated purpose of these associations bore a striking resemblance to one another throughout Austria; members of the Kameradschaftsbünde tended to be members of the Verband der Unabhängigen (an organization that would crystalize as the FPÖ by $1955 / 56)^{40}$ and the ÖVP who shared similar sentiments with respect to their wartime experiences. The bylaws of provincial associations were often worded vaguely, allowing politically conservative men to promote problematic-and for the Socialists and Communists (KPÖ) on the political

36. On the evolution of this legislation, see Stiefel, Entnazifizierung, 81-88.

37. Wilhelm Svoboda, “.... vorbehaltlos meine Pflicht erfüllt': Das Internierungslager Glasenbach (Camp 'Marcus W. Orr')," Zeitgeschichte 22 (1995); esp. 12-15. Svoboda's essay examines the reintroduction into civic life of former Nazis held at the Glasenbach detention camp, including the reconstitution of the German-national/liberal camp and the commemorative activities of veterans. See also Albrich, "'Es gibt keine jüdische Frage," 155-59. Albrich points out that because the Western Allies' had insisted firmly that Austria's status as victim be recognized in State Treaty negotiations beginning in 1947, many of the Minderbelasteten given amnesty and reintegrated into Austrian society felt entitled to argue that they had been victimized twice over-once by the great "Prussian swindle," then by the Allies' insistence that they be marginalized after the war. An effect of this development was that Austrian Jews were denied a particular victim status when pursuing restitution claims; the Austrian government, in the interest of "fairness" to amnestied former Nazis, refused to recognize distinctions among its citizens, all of whom were to be regarded equally as victims of the National Socialist regime. Austrian Jews were not permitted to pursue reparations until 
Left, rather dangerous-notions of fatherland, duty, sacrifice, and remembrance. Camaraderie and the sustenance of the soldierly ideal nurtured the identities of members of Austrian as well as German associations. Paragraph 2 of the uniform statutes code for the provincial Salzburg branch of the Kameradschaftsbund, for example, listed among its purposes and goals a number of points common to virtually all regional associations:

- Promotion of traditional Austrian fatherland and homeland conceptions [Vaterlands-und Heimatsgedanken], as well as the cultivation of comradeship among members...

- Arrangement of ceremonies in memory of the dead and missing of both [world] wars, the care of the burying places of comrades killed in action and [otherwise] dead,

- Creation of monuments in honor of the dead and missing of both wars,

- Comradely proceedings of all kinds for the promotion of sociability ... ${ }^{41}$

Despite the seemingly innocuous wording of these stated purposes, implicit within them was a celebration of communitas fraught with values dangerous to the principles upon which the Second Republic was founded. Many Austrians who had served in the Third Reich's armed forces eagerly communed with others who had shared the experience of warfare-as-crusade. This had much to do with the transformative effect of conflict on the Eastern Front, but was perhaps even more an expression of the often-repeated theme of struggle in Nazi ideology. One need not have been a nominal or a convinced Nazi to perceive the war as a life-and-death struggle between Germans as Europe's cultural vanguard and the destructive force of barbaric "Judeo-Bolshevism"-particularly in the context of a racially-driven war of conquest that had become a war for survival by the end of 1942 .

Mosse's evaluation of the nature and perceived purpose of German veterans' associations also holds true to a significant degree for their Austrian counterparts in the following respect:

well after the State Treaty was signed in 1955 . On the notion of politics of memory and victimization in the West German context $\rightarrow$ Robert G. Moeller, "War Stories:The Search for a Usable Past in the Federal Republic of Germany," American Historical Review 101 (1996): 1008-48.

38. Heidemarie Uhl, "The Politics of Memory: Austria's Perception of the Second World War and the National Socialist Period," Contemporary Austrian Studies 5 (1996): 75.

39. ÖStA/AdR, BMLV 3.556-Präs/I/57. Sicherheitsdirektion für das Bundesland Salzburg. Übersicht über die im Amtsbereiche der Bundespolizeidirektion und Bezirkshauptmannschaft Salzburg-Umgebung mit dem Stande vom 1.8.1956 bestehenden Kameradschafts-, Krieger-, Schützen- und Vereinen ähnlicher Art sowie von Vereinen, die sich mit dem Flugwesen befassen.

40. The Verband der Unabhängigen ( $\mathrm{VdU}$ ) was a curious combination of former Nazis and Deutschnationale types, as well as old-time Liberals who felt they could not find a home on the right wing of the SPÖ or the left wing of the ÖVP.

41. ÖStA/AdR, BMLV 3.556-Präs/I/57. "Statuten des österreichischen Kameradschaftsbundes, Landesverband Salzburg, Kameradschaft Maxglan, 27; Statuten des österreichischen Kameradschaftsbundes, Landesverband Salzburg, Kameradschaft Pfarrwerfen, 225. 
Camaraderie lost its aggressive implications-the band of comrades against the world - and yet something of the older ideal remained, perhaps lying in wait to revive the Myth of the War Experience. Close to the center of the ideal of camaraderie had been the vision of the so-called new man. An effort was made in Germany after the Second World War to save this soldierly ideal. The most obvious attempt was the continuing glorification of the SS both as new men and as paradigms of camaraderie. The veterans of the SS lamented, logically enough, that the fallen had not yet received monuments of iron and bronze, and that heroes' groves of the First World War now served merely as picnic grounds for weary urbanites. ${ }^{42}$

A significant number of soldiers who had fought to protect Austria from "bombs, misery, hunger, need, and the Russians"-whether or not their understanding of these dangers were refracted through a Nazi prism-were dismayed, even insulted, that federal legislation obliged the government to employ Austrian officials and devote Austrian resources to the maintenance and security of Allied military cemeteries and monuments. Despoiling these graves and memorials was designated a felony and carried a maximum punishment of five years' imprisonment. ${ }^{43}$ Austrian dead from both world wars were not neglected; yet, while legislation guaranteed public maintenance of Austrian graves and monuments, no federal stipulations were enacted with the legislation to punish those who might deface them. ${ }^{44}$ Although official commemoration represented a nod toward the "cult of the fallen soldier," for veterans who regarded their participation in the war as a sanctified experience this official measure did not demonstrate sufficient respect for the supreme sacrifice for Vaterland and Heimat. By way of contrast, disgruntled veterans could point to the Nazi regime's consecration of the "highest expression of duty," 45 without bothering to consider the contextual significance of such duty for Austrians encouraged to disassociate themselves from völkisch connotations of Vaterland, Volk, or Heimat.

42. Mosse, Fallen Soldiers, 217.

43. ÖStA/AdR, BMI 56.779-9/1948, Bundesgesetz über die Fürsorge für Kriegsgräber und für Kriegerdenkmäler aus dem 2. Weltkrieg, Referententwurf. See also BGB1. 1948/176, 670: Bundesgesetz vom 7. Juli 1948 über die Fürsorge und den Schutz der Kriegsgräber und Kriegerdenkmäler aus dem zweiten Weltkrieg für Angehörige der Alliierten, Vereinten Nationen und für Opfer des Kampfes um ein freies, demokratisches Österreich und Opfer politischer Verfolgung.

44. BGB1. 1948/175, 669-70: Bundesgesetz vom 7. Juli 1948 über die Fürgsorge für Kriegsgräber aus dem ersten und zweiten Weltkrieg. On the commemoration of First World War veterans through momuments and heroes groves, see also Stefan Riesenfellner, "Todeszeichen: Zeitgeschichtliche Denkmalkultur am Beispiel von Kriegerdenkmälern in Graz und in der Steiermark von 1867-1934," in Riesenfellner and Uhl, Todeszeichen, esp. 17-69.

45. See Friedrich Grassegger, "'Auch Tote stehn in unsern Reihn': Nationalsozialistische Denkmäler des Totengedenkens in der Steiermark (1938-1945)" in Riesenfellner and Uhl, Todeszeichen, 99-110. 
Provocative collaborative studies of Austrian memorials from the two world wars by Stefan Riesenfellner and Heidemarie Uhl and by Reinhold Gärtner and Sieglinde Rosenberger have underscored the importance of Heimat sentiments in commemorative installations, especially in those instances where tribute was paid to the memory of Nazi era veterans. These men, "who swore an oath of loyalty to Hitler, were honored as 'Heroes of the Heimat.' In no case is the Wehrmacht remembered as a foreign military power that destroyed Austrian sovereignty ... It is also suppressed that this destruction of Austria was implemented with the considerable assistance of Austrians." ${ }^{.46}$ One recognizes in these commemorative statements precisely what Leed refers to in all Europeans lands after 1918 as "organized mourning ... the most acceptable way in which the war continued to define the identities of combatants." ${ }^{\prime 7}$ Monuments and plaques tended to be constructed in places of special significance, in the public squares or cemeteries of quiet little rural villages and small towns dominated by conservative councils. There the Soldatentreffen took on the quality of a religious ritual, with a march/pilgrimage to a designated site where the commemoration, or celebration, of the sanctified Fronterlebnis occurred, the participants dressed customarily - and illegally - in old Wehrmacht or SS garb, the procession accompanied by patriotic music and singing. ${ }^{48}$ The local pastor, former unit commanders, and town dignitaries would speak to the assembled veterans about the heroic sacrifice for home and hearth rendered by the living and the dead of the Frontgemeinschaft, and great ceremony attended the care of the etemal flame for the dead. ${ }^{49}$ Monuments to soldiers who fell in the service of the Third Reich, Uhl notes, outnumber vastly those to the victims of National Socialist terror. The monuments and graves of the latter-Jews, concentration camp inmates, or deserters who were either murdered or suffered inhuman treatment-tend to be relegated to the margins of cemeteries or other inconspicuous locations. ${ }^{50}$

Thorny issues of "duty" and "service" surface here again, for the "Austrianness" of the living and the dead had been denied during the war-in many instances by the soldiers themselves, definitely by the NS-Regime-in

46. Gärtner and Rosenberger, Kriegerdenkmäler, 28-29. Uhl, "Erinnerung undVersöhnung," $147 f$.

47. Leed, No Man's Land, 212.

48. The linkage between Turner's understanding of the medieval pilgrimage as traditional, religious social drama and the personal and social-political nature of the Soldatentreffen as quasi-religious social drama is compelling. See Turner, Dramas, Fields, and Metaphors, 175-77.

49. Gärtner and Rosenberger, Kriegerdenkmäler, 67-84, 107, 118ff. For an examination of elements of continuity from post-First World War to post-1945 commemoration, see Winter, Sites of Memory, 82-98. The impressive breadth of Winter's study addresses this theme in a pan-European context.

50. Uhl, "Erinnerung und Versöhnung"; idem, "Erinnern und Vergessen: Denkmäler zur Erinnerung an die Opfer der nationalsozialistischen Gewaltherrschaft und an die Gefallenen des zweiten Weltkriegs in Graz und in der Steiermark," in Riesenfellner and Uhl, Todeszeichen, 111-95. 
favor of their inclusion into the German Volksgemeinschaff. ${ }^{51}$ It should be noted, however, that because war memorials frequently offer the only commemorative expression in the smaller localities where Soldatentreffen were so frequently staged, such monuments tend to "institute a relationship to and a presentation of the past ... that reduces the perception of warfare to one of normality," even to the extent of glossing over the years 1938-45 and casting the enemy (invariably the Russians) in an unfavorable light. The end result has tended to be the legitimization of duty-encoded memory of the war experience nurtured by Kameradschaftsbünde members at the expense of careful reflection on either the officially established myth of victimization or on suffering inflicted upon others. ${ }^{52}$ As an official Kameradschafisbund position in one weekly newspaper stated triumphantly in late 1952, "[While] during 1945 and thereafter the soldier was defamed in every conceivable way ... a healthy perspective has spread through Austria by now." 53

Far less documentation exists concerning Soldatentreffen before the conclusion of the State Treaty in May 1955 than afterward. Certainly a reasonable explanation for the existence of only a sketchy record of reunions is that they occurred somewhat less frequently and more surreptitiously than those Kameradschaftsbünde activities which took place after 1955. Because the broader political consequence of Soldatentreffen was far riskier prior to the restoration of full sovereignty, concerned Austrian authorities minimized their incidence and significance, and veterans themselves very rarely chose a public forum in which to challenge the Lebenslüge. Moreover, the ever-present suspicion of manifestly unrepentant militaristic sentiment provided the occupying powers during the early 1950s-particularly France and Russia - with a pretext for questioning the continuation of negotiations with the Austrian government toward a treaty and for maintaining their military presence at the expense of Austrian taxpayers. Consequently, prior to the spring of 1955, the ÖVP-SPÖ coalition viewed Soldatentreffen and the steady appearance of West German Kameradschaftsverbände publications across the Austrian border with great alarrn. The concern about the latter was no trifling matter, for it represented a fundamental violation of the occupiers' criteria for a democratic Austrian press. The minutes of the Executive Council of the Allied Control Commission offer valuable insights in such instances. The Allied authorities ordered embarrassed Austrian officials to impose sanctions against newspapers or periodicals in Austria for violations of

51. Ernst Hanisch, "Die Präsenz des Dritten Reiches in der Zweiten Republik," in Kos and Regele, Inventur 45/55, $45 f$.

52. Gärtner and Rosenberger, Kriegerdenkmäler, 49-50.

53. "Ehrenrettung des Soldaten," Sonntagspost, 30 November 1952. Newspaper articles cited in this essay do not include page numbers; the clipped citations were researched in the files of the Arbeiterkammer für Wien-Dokumentation. 
the Press Decree, particularly insofar as the importation, distribution, and sale of such literature was concerned.

Uniform implementation of such measures proved difficult at best, even though communications between Vienna and the provincial authorities were consistent on the matter. The difficulty stemmed primarily from the fact that the Austrian-West German border remained too porous to control effectively the small numbers of copies of contraband literature. This literature could then be reproduced in Austria. In such cases the Allies justified the right to engage in press controls in order to "assist the Austrian Government to recreate a sound and democratic national life based on an efficient administration, stable economic and financial conditions and respect for law and order" and to "ensure the institution of a progressive long-term educational program designed to eradicate all traces of Nazi ideology and to foster democratic principles among Austrian youth. ${ }^{54}$ Perhaps the most informative evidence regarding Austrian Soldatentreffen comes from the West German diplomatic corps, however. West German concerns with anti-Soviet and pro-German national sentiments within segments of the Austrian population were relayed in May 1954 to Bruno Kreisky, then undersecretary in the Foreign Department of the Austrian Chancellery. According to Kreisky's report, the German envoy Müller-Graaf had expressed profound dismay that the frequency of Soldatentreffen involving German and Austrian veterans and other right-wing Austrian-German cultural initiatives, the participation of large crowds, and the "tactlessness on the part of the German guests" streaming over the border in bus caravans, or on chartered trains, as well as the behavior of their Austrian hosts, had elicited Soviet and French fears of a new Anschluss-an apprehension exacerbated by measures discussed within Austria, initiated and championed chiefly by the VdU, to abolish the visa requirement for travel between West Germany and Austria. ${ }^{55}$ Moreover, Müller-Graaf objected to a wealth of literature glorifying war and the Nazi era that he had encountered at the Graz Book Fair. Kreisky noted in this connection that "[Müller-Graaf] was compelled to tell me, unfortunately, that such a thing would not be possible at a German fair, and that, to be sure, [in Germany] the interest in this literature is apparently not as great as in Austria." 56

In a separate report to Chancellor Adenauer, Müller-Graaf emphasized his concern that a growing inclination for a new Anschluss had found expression in the non-Soviet occupied portions of Austria. This behavior manifested itself in a number of ways: an Innsbruck hotelier's enthusiastic celebration of the

54. ÖStA/AdR, BKA 6.478-III/SEC/51, Control Agreement for Austria, 28 June 1946, Articles 3c) and e). See also the Executive Council's discussion over censorship of the Deutsche-SoldatenZeitung in EXCO/P(52)41 (no minute number), 16 April 1952, and the follow-up meeting, EXCO/P(52)41, Minute \#1565, 16 May 1952.

55. StBKA,VII, Staatssekretär, Mappe "Deutschland," 1-2.

56. Ibid., 2 
German Bundestag elections by having the Deutschlandlied played, to the horror of the assembled guests of diverse nationalities, and ex-Field Marshal Kesselring's trip to Austria-in violation of an expression of strong disapproval on the part of Austria's Interior Minister, Oskar Helmer (SPÖ)-to address assembled Austrian veterans in full NS-era uniforms and decorations. MüllerGraaf concluded with an exhortation that the West German and Austrian governments agree to cooperate in a crackdown against German-Austrian Soldatentreffen on both sides of the border. To this end, Müller-Graaf had made a personal entreaty to the Bavarian minister president to police these events. ${ }^{57}$ The anxiety expressed by the Foreign Ministry in Bonn represents an unequivocal expression of official West German antipathy toward Soldatentreffen and Anschluss sentiment. Indeed, Müller-Graaf's alarm vis-à-vis developments in Austria reflected the West German govemment's concern that expressions of soldierly camaraderie and aggressive pan-German sentiment would derail the delicate ongoing diplomatic work toward future German reunification.

Complaints raised by the Soviet occupation authorities concerning the celebration of military values and the expression of Anschluss sentiments would have been easier for Austrian officials to shrug off if it were solely a matter of small groups of veterans gathering in isolated locations to engage in the commemoration of comradeship and sacrifice. Far more damaging to Austrian credibility was the toleration, and in some cases outright support, extended to Kameradschafisbünde by those entrusted with monitoring them:Austrian officials. Compelled to exercise damage control, Chancellor Julius Raab (ÖVP) dismissed Soviet concerns in a speech before parliament in May 1954 with the emphatic statement, "No one in Austria thinks of an Anschluss!"-despite Soviet and Austrian communist claims that the copresence of German and Austrian veterans represented an upsurge in potential support for a closer West GermanAustrian connection. ${ }^{58}$ Raab added, with support from the assembled SPÖ and ÖVP representatives, that:

[S]uch a personal meeting has nothing to do with military aims. The Austrian authorities regularly demand-and shall continue to do so in the futurethat these meetings refrain from any and all political activities. I believe that

57. StBKA, VII, Staatssekretär, Mappe "Deutschland:" Box-BMfAA Bonn, Österreichbezüge I, Mappe 5, 2-3. See also ALCO/7(54)218, Minute \#1868f, 14 May 1954, in which the Russian High Commissioner Ilichev raised pointed objections against the "further and considerable strengthening of fascistic and militaristic tendencies in Austria," through Kameradschaftsbünde led by former Nazi generals, "in uniforms of the Hitler-Wehrmacht with decorations and rank designations," as well as against the extension of these connections between like-minded bodies in the Federal Republic of Germany and Austria. The French High Commissioner Payart expressed similar concerns to Müller-Graaf, particularly with respect to the fanfare generated by the Kameradschaftsbünde to accompany the Kesselring visit.

58. Raab, "Erklärung der Bundesregierung," Sten.Prot.NR,VII. G.P., 39th Session, 19 May 1954, 1,626 . 
these soldiers' reunions will soon have run their course. In no way does the Austrian government condone the participation of high military leaders of Hitler's army in such reunions. ${ }^{59}$

Despite the chancellor's denial, these meetings did, in fact, have an implicitly political content, particularly when one considers the tone of VdU pronouncements regarding Soldatentreffen. In an effort to explain that his party's support for Kameradschaftsbünde and reunions was apolitical, the former Wehrmacht officer and veterans' group member Max Stendebach advocated a position that exemplified the persistence of the very pan-German sentiments that Raab had denied existed within Austria. According to Stendebach, the concept of the nation-state had proven itself not viable in the twentieth century, and efforts to use force to unite nations into states had created nothing but deplorable violence and misery. Thus, he concluded, discussion of a future Anschluss was not on the agenda. ${ }^{60}$ Nonetheless, Stendebach added ominously that Austria and Germany shared an incontestable, long-standing connection, expressed in the fellowship of participants at Soldatentreffen:

I have expressed myself plainly and clearly in favor of Austrian independence but have also said: [with respect to] national connections, the border [between Germany and Austria] is nonexistent for us, it is of no significance. If we have this point of view, why should we still be induced to generate Anschluss propaganda? ${ }^{31}$

Such statements did little to reassure the Allied Control Commission that potentially revanchist sentiment had been rooted out of Austrian political culture.

59. Ibid., 1,627. The ÖVP parliamentarian Lujo Toncic-Sorinj added the measured comment "[We must appreciate the fact] that the soldiers of both world wars want to meet and to exchange their shared experiences. There is hardly an event that continues to affect a man's soul as that of the war- and front experience. We are, of course, entirely opposed to the misuse of these soldiers' reunions for any other purposes. The participants of these meetings should also ask themselves whether, aside from their admittedly legitimate interests in keeping alive a shared tradition, they contribute something positive to the present Austrian state. One cannot live only in the past, and especially former soldiers have the duty to consider whether, through these activities, they may cause trouble for Austria." Sten.Prot.NR,VII. G.P., 39th Session, 19 May 1954, 1,636. For a critical ÖVP perspective on Kameradschaftsbünde and Soldatentreffen, see also the ÖVP magazine Der Aufbruch (1958/9): 28, in which the politically moderate author criticizes the cultivation of tradition in veterans' associations: “ . . here and there stir the spirits of those who dwell in the past. Not only in Germany, but in Austria too. Out of every corner and crack they creep forward in many forms and recount their old songs: of Reich, of death, of glory. They prattle their half-truths in taverns and at Kameradschaftstreffen. They confuse heroism with megalomania, readiness to sacrifice with heroic death on the field of their interests. They abuse, in order to win the youth, the dead of the last war, for their 'new concept'." Cited in Sten.Prot.NR,VIII. G.P., 69th Session, 3 December $1958,3,185$.

60. Stendebach, Sten.Prot.NR, VII. G.P., 39th Session, 19 May 1954, 1,651.

61. Ibid. 
If members of the governing Catholic conservative-social democratic coalition shared Raab's optimism that the activity of Kameradschaftsbünde would soon abate, a second, enthusiastic wave of Soldatentreffen and commemoration after the state treaty revealed to them their naiveté. These associations had always expressed overwhelmingly anti-Soviet sentiments in newspaper articles or editorials, and government officials had hoped that the impetus for such a disposition would be eliminated upon withdrawal of the unwelcome Soviet military presence. $^{62}$ Rather than abate, however, the anti-Soviet tone of the veterans' association rhetoric actually intensified after USSR occupation forces left Austria by the end of 1955 . Members of Kameradschaftsbünde fancied that their activities had represented a kind of spiritual resistance to Soviet occupation. Thus, the withdrawal of Soviet troops represented a moral, even quasi-military victory for many who had fought on the eastern front between 1941 and 1945.The "offensive war in defense of Vaterland and Heimat" carried out over ten years with the same steadfastness as the war on the Ostfront had been waged-albeit with very different means-had resulted in a delayed, yet monumental victory over bolshevism, and confirmed for conservative-minded veterans that these associations could serve as a medium through which the exorcism of the red menace could and should be celebrated. ${ }^{63}$ "Victory" over the Russians via the State Treaty in 1955 enabled Kameradschaftsbund advocates, such as the FPÖ parliamentary deputy Fritz Stüber, to draw the tenuous, provocative conclusion from a linkage of Nazi antibolshevism with Cold War-era antipathy toward the Soviet Union that deeds committed during the war, and since 1945 condemned as criminal, could now be brazenly justified or relativized.

After, at Nuremberg and elsewhere, German execution of hostages and measures of reprisal against guerillas and partisans were declared crimes against humanity and punished with thousands of death sentences and thousands of years of imprisonment, after the entire German people were branded with

62. Soviet representatives to the Allied Commission took extreme interest in the censorship of the Austrian press, where their American, British, and French counterparts, reluctant to introduce controls without absolute certainty that books and newspapers in question possessed pro-Nazi, panGerman revanchist, militaristic, or anti-Allied content, frequently checked Soviet designs. See discussion of the periodical Berichte und Informationen and the newspapers Echo der Heimat and Wochen Echo in EXCO/M(51)182, Minute \#2319, 2 March 1951 and EXCO/P(51)185, Minute \#2354, 20 April 195 1, as well as review of von Cholitz's Soldat unter Soldaten, EXCO/P(53)43, Minute \#2823, 17 April 1953 and von Papen's Die Wahrheit: Eine Gasse, EXCO/P(53)40, Minute \#2812, 2 April 1953. Echo der Heimat was eventually banned under ACA orders when its editor crossed the line separating cautious apology from outright glorification of Nazi foreign policy. See EXCO/P(52)50, Minute \#2595, 7 May 1952.

63. In this light, the selfsame certitude of the "ultimately victorious" veterans in 1955 was expressed in the fervor of a junior Wehrmacht officer trapped in Stalingrad in late 1942: "This war compels us again to make the deepest exertion of all of our powers. . . But still we want to hold on because we know: it must be done for our own, for our children's, and our people's future ..." Cited in Fritz, Frontsoldaten, 214. 
the shame of Oradour and Lidice, and very soon after the ashes of the hanged and burned were scattered to the winds and the flesh of the executed German officers and men has hardly decomposed, French troops are hurling bombs and grenades into villages in Morocco against a civilian population (admittedly a refractory one). France sat as judge at Nuremberg and there issued its damning judgment for deeds similar to those she has now committed in North Africa, with an air of ingenuousness, as military necessity. ${ }^{64}$

At other moments, Kameradschaftsbund supporters accounted for deeds done by Austrians and Germans in uniforms of the Third Reich with language far less controversial and confrontational, invoking a kind of grand international and transhistorical fraternity of frontsoldiery with an almost conspiratorial wink. In this vein, the FPÖ parliamentarian Heinrich Zechmann, another veterans' advocate asserted "soldiers are always soldiers, the same thing is demanded from soldiers everywhere..."65 Not unlike right-wing veterans after 1918, Kameradschaftsbund members projected an image of the veteran as the servant of his national community, with an understanding of the needs of Volk and Heimat far superior to that of leftist politicians and their ostensibly divisive class-driven political concerns. ${ }^{66}$

\section{Commemoration of Comradeship after 1955}

Once the State Treaty restored Austrian sovereignty, ending the occupation powers' authority formally, a second, and in many respects higher profile, wave of Kameradschaftsbund activity surfaced. Barely a week after the treaty was signed, Ferdinand Graf, a leading Interior Ministry official and later the Second Republic's first defense minister, addressed a Soldatentreffen at Bad St. Leonhardt im Lavanttal, Styria, at which members of veterans' associations appeared in old imperial, First Republic, Wehrmacht, and current Second Republic Bundesheer (federal army) attire. According to Graf it was not the uniform, but the character of the man who wore it that distinguished the soldier from the war criminal, reactionary, or fascist. ${ }^{67}$ In one particularly ostentatious, but by no means isolated display of solidarity, a veterans' gathering of uniformed former WaffenSS men took place in Innsbruck with the apparent blessing of the ÖVP mayor. The keynote speaker was a former SS general and West German citizen. An

64. Fritz Stüber, Sten.Prot.NR,VII. G.P., 77th Session, 7 September 1955, 3,491. My italics. For many of the former Nazis and SS men who had been held in what they designated exaggeratedly as the "concentration camps" of Glasenbach and Wolsberg-detention facilities for war criminals, Minderbelastete, and prominent Nazis operated by the U.S. and British occupation authorities, respectively, into the later 1940 s- the State Treaty may very well have been regarded as a victory over the Anglo-Americans as well. See Svoboda, " Das Internierungslager Glasenbach."

65. Heinrich Zechmann, Sten.Prot.NR,VII. G.P., 69th Session, 3 December 1958, 3,183.

66. Leed, No Man's Land, 196.

67. "Zwischen 'Ohne uns' und '08/15,'” Österreichische Neue Tageszeitung, 24 May 1955. The event occurred on May 23rd. 
address was also delivered by the regional Bundesheer commandant, who, according to newspaper reports, praised the "comradely connection" of soldiers of the Austrian Second Republic and former Austrian members of the Wehrmacht "to members of the former Waffen-SS." 68 Self-congratulatory speeches emphasized "duty well done" and praised sacrifices offered bravely for the honor and giory of Volk and Vaterland. The initially solemn commemoration concluded with copious eating and spirited drinking. In yet another highly publicized incident on 15 September 1958, a Soldatentreffen occurred at Hainburg an der Donau, directly across the Austrian-Czechoslovak border from Bratislava, at which the mayor (this time a Socialist) presided over a gathering of former Wehrmacht soldiers wearing their old uniforms and decorations. The local Bundesheer unit provided its band to play marching music and to accompany the field mass celebrated by the parish priest. ${ }^{69}$

Events of this kind violated the legislative ban on wearing Third Reich uniforms and emblems, and represented an embarrassing challenge to an Austrian political culture founded on the myth of victimization and the tacit injunction against any behavior which called the myth into question. If the actions of exsoldiers were not trouble enough for the government, a number of senior noncommissioned and commissioned Bundesheer officers with World War II combat experience clearly did not take this prohibition seriously, even arriving occasionally at Soldatentreffen in the uniforms of their First Republic or Third Reich military service. These actions violated not only Austrian law; they also contravened $\$ 20$ of the Bundesheer General Service Regulations Code, which mandated that members of the Austrian armed forces wear only the military uniform of the Second Republic. It is quite evident, though, that enforcement of such codes proved extraordinarily difficult, particularly because local FPÖ, ÖVP, and occasionally even SPÖ officials were sympathetic to the creation, goals, and festive gatherings of Kameradschaftsbünde, in some cases they were even enthusiastically supportive. ${ }^{70}$ Participants and patrons alike seemed unconcerned that such sentiments and activities called into question the official Austrian rejection of National Socialism and the glorification of martial values, and represented an affront to the high-minded principle of freedom of assembly and expression when behaviors expressed antidemocratic sentiment. The activities of Kameradschaftsbünde and the firm support lent to them by FPÖ leaders and certain prominent conservative Catholic politicians alarmed those con-

68. ÖStA/AdR, BMLV 44.542-Wpol/58. The Bundesheer's political division regularly monitored such reports. The case was reported by both the communist Volksstimme, 23 August 1958 and the moderate Salzburger Tageblatt, 23 August 1958.

69. ÖStA/AdR, BMLV PID/III/5d/58.

70. A hearty repect for martial values was a common sentiment among a great many conservative Catholics. Part of their emotional compensation for Austria's status as a small, divided state was the glorification of the power and majesty of the Habsburg Empire, including its military tradition. 
cerned with a resurgent romanticization of warfare. For Communists, Social Democrats, and progressive circles within the ÖVP, the values, goals, and symbolic action common to veterans' associations throughout Austria elicited unsettling memories of fascist glorification of the military. As a countermeasure, during the later 1950s, left wing journalists vigorously denounced reunions involving former Waffen-SS men and Wehrmacht members, taking it upon themselves to remain vigilant against Soldatentreffen on behalf of the republic.

The Communists, with their proud and legitimate claim as the most active antifascist resistance group, wanted no part in these veterans' associations, and the groups were pleased to accommodate their scruples. ${ }^{71}$ In many instances, Kameradschaftsbünde charters included clauses which, in addition to requiring military service in either world war, demanded that prospective members were men who "lead an ethically irreproachable life"-a coded reference to "pious" and conservative-minded individuals. "72 "Godless Reds," those who had opposed either the First or the Second World War (even though they might have participated in them), and other somehow suspect (i.e., leftist) prospective members would have found themselves unwelcome. The incorporation of illconcealed antileftist, antipacifist, and antirevisionist clauses in Kameradschaftsbund statutes and the tendency for commemorative monuments to eschew reference to those who died as a result of their opposition to the Nazi regime amounted to a delegitimization of those who questioned Frontgemeinschaft values and rejected NS-encoded notions of duty and honor. ${ }^{73}$

Opinion within the Social Democratic camp on membership in Kameradschaftsbünde was divided. A vocal group composed largely of left-wing party members feared the potential for veterans' associations, particularly those organized as shooting clubs, to assume the militant antisocialist, antidemocratic quality of Austria's interwar fascist paramilitary. This concern was underscored when a number of associations in Tyrol and Vorarlberg sought federal authorization to carry rifles, in order that they might serve as territorial militias. ${ }^{74}$ Others within the SPÖ feared that the rival superpowers might capitalize on a general resurgence of militaristic spirit to press European youth into service in preparation for a future East-West conflict. Prior to the creation of the

71. On the KPÖ's resistance activity, see Radomir Luza, The Resistance in Austria (Minneapolis, 1984), 99-155.

72. See for example ÖStA/AdR, BMLV (BKA/ALV) 241.751-Präs/56. Sicherheitsdirektion für das Bundesland Niederösterreich (Z1. 7.754/1 -SD), betr. Bildung von Kameradschafts-und Schützenvereinen; Meldung, 25 September 1956. Statuten der Heimkehrervereinigung Obritz (Bezirk Hollabrunn) \$3, 2.

73. See again Uhl, "Erinnerung als Versöhnung," esp. 149ff.

74. Neues Österreich, 6 May 1959. The Interior Ministry refused to sanction the distribution of weapons to private associations. These "local defense associations," in turn, rejected a suggestion that they be incorporated into the Bundesheer as as kind of reserve corps, not unlike the National Guard in the United States. 
Bundesheer in mid-1955, these Social Democrats had voiced concern that Kameradschaftsbünde might provide the backbone for a reactionary federal army, just as it had during the 1920s, with the possibility that Austrian and other European Social Democratic labor movements might be crushed by right-wing dominated military forces. ${ }^{75}$ The party's official position on veterans' associations was voiced by the SPÖ Central Secretary Otto Probst, however, who argued that party members should seek entrance into such groups precisely because of the possibility of lingering fascist inclinations in veterans' groups. A social democratic presence, Probst argued, would contribute effectively to nipping these sentiments in the bud.

It is up to the party delegations in the provinces to oversee the activities of the Österreichische Kameradschafssbund and to call upon their members active therein to thwart all attempts and demonstrations that would be of a military character and at the same time to prevent the subjection of the Kameradschaftsbund to the decisions of the Österreichische Volkspartei. Members of the Socialist Party, insofar as they belong to the Kameradschaftsbund, must make sure that the latter is not misused for political purposes and that its members do not take part in gatherings, demonstrations, or other events which violate the constitutional laws of our democratic republic or which could do harm to the reputation, dignity, and honor of our people and our state. ${ }^{76}$

Despite the party's official, rather naive belief that veterans' groups might assume a new character through the quasi-conspiratorial activity of a very small group of Social Democrats, the SPÖ was not at all prepared to discontinue its criticisms of these associations. All in all, if left-wing vigilance did not always result in the implementation of restrictions against Kameradschaftsbünde activities, its watchdog role helped to heighten public awareness of the potential danger and very real embarrassment represented by the existence of such organizations. ${ }^{77}$ This was particularly true where Social Democratic activity was concerned; while the Communists were tainted in the eyes of most Austrians because of their intimate connection to the hated and feared Soviet occupation forces in

75. See Fritz Konir and Anton Mayrhauser, SPÖ-PTP 1953, 94-95 and 97, respectively.

76. Probst conveyed the party leadership's position, drafted a month earlier, to the assembled conference delegates: Probst, PTP 1953, 110.Those who shared his perspectives added that Socialists had served admirably as soldiers since 1934, and suggested that if the organizations were politically inoculated through SPÖ members, such associations might provide useful locations for the cultivntion of pro-Austrian sentiment. See also the statement delivered by the Salzburg-Stadt representative Kurt Preussler, a decorated Social Democratic veteran, SPÖ-PTP 1953, $104 \mathrm{f}$.

77. The KPÖ party chief Johann Koplenig criticized the tendency of participants at festive veterans' reunions, with their fond reminiscences of the war years, to represent a conflict in which millions died and many more suffered as a kind of "Sozialtourismus in field gray [feldgrau]." Sten.Prot.NR,VIII. G.P., 42nd Session, 4 December 1957, 1,735. 
Eastern Austria, Social Democrats could criticize the seemingly unrepentant disposition of veterans' groups without being dismissed as Russian lackeys.

Feckless, apologetic statements such as Heinrich Zechmann's "soldiers will be soldiers" had long antagonized members of the left-wing parties and progressive Volkspartei supporters. With the end of the occupation, Social Democrats, in particular, felt compelled to check the enthusiasm with vigilance and criticism. SPÖ critics energetically pointed out the danger in linking duty-including acts of brutality committed under the National Socialist banner-with the sentimental "cultivation of tradition" that Kameradschaftsbünde arrogated to themselves. In doing so, however, Social Democratic derogators themselves tended to avoid championing a critical position on the vexing, unresolved question of the individual soldier's culpability for war crimes, given, as noted, that many soldiers, even if they had not been Nazis, had been socialized through schooling and military training to accept certain NS precepts-some of which may have been not entirely unlike positions supported before the Anschluss (e.g., virulent anticommunism, racist anti-Semitism). Rather than confront this difficult element of a more comprehensive Vergangenheitsbewältigung, the SPÖ directed its concerns to the future, to the gradual transformation of Austria toward a social democratic society based on principles of cooperation, solidarity, pacifism, and social justice. This future-orientation, which served to repress confrontation with the past in its own right found two principle forms of expression. Many a Social Democratic mayor or municipal official tolerated violations of the law prohibiting the wearing of Nazi symbols, if only for reasons of political expediency. Given the large number of veterans among the Austrian electorate, first with the enfranchisement of the Minderbelasteten in 1949, later with the return of thousands of Austrian prisoners of war from Soviet detention throughout the early and middle 1950s, SPÖ leaders at the local, provincial, and federal level recognized the importance of winning the electoral support of veterans. ${ }^{78}$ Second, as a party coresponsible for governing Austria, the SPÖ felt caught between its conviction that the increasingly vocal presence of Kameradschaftsbünde required firm legal countermeasures and its own reluctance to violate the taboo protecting the fragile belief in Austrian victimization. Accordingly, Social Democratic rhetoric vis-à-vis veterans' groups differed from the sharp, accusatory style of the Communists, which depicted every Kameradschaftsbund member as a would-be harbinger of a second Anschluss. ${ }^{79}$

78. See Svoboda, "Das Internierungslager Glasenbach," 12-16.

79. Volksstimme editorials and the statements of Communist politicians were couched routinely in accusatory fashion, often expressed as rhetorical questions:"The Landser who had spent so many years with each other and had lain in the mud together would like to see one another again, exchange their memories and what has become of their 'buddies.'Yet why are these mass meetings necessary if they want to see friends again? A private reunion gives, indeed, far more opportunity to exchange memories. And why do Kameradschaftstreffen almost always become political demonstrations?" "Biertisch, Westerwald, und Hakenkreuz," Österreichische Volksstimme, 10 August 1958. 
Throughout the 1950s SPÖ critics of veterans' groups focused on the violation of legal ordinances against wearing Third Reich uniforms and emblems so common at veterans' gatherings and against the politicized activity of Bundesheer personnel at rallies and reunions. By the end of the decade, persistent criticism from the political left appears to have succeeded in propelling the ÖVP-dominated chancellery toward demonstrating an interest in enforcing the law against the wearing of Wehrmacht or SS uniforms, as well as preventing the attendance of uniformed Bundesheer servicemen at reunions. ${ }^{80}$ The tendency for many of the veterans present at such gatherings and commemorations to wear World War II decorations complete with swastika recalled unsavory political sentiments, and the Socialists, increasingly concerned with issues of federally-managed staatsbürgerliche Erziehung (civics education)-especially for children, in the interest of a genuinely democratic future civic culture-pointed out that this form of expression, itself implicitly political, presented to members of the younger generation an ambiguous message regarding the Nazi period. ${ }^{81}$ Gradually, ÖVP officials in the chancellery came to see Kameradschaftsbünde and their activities as symbolic expressions of not merely confused, but more importantly volatile political sentiments. This recognition resulted in overwhelming parliamentary support for legislation in 1960 that forbade "wearing or otherwise displaying the symbols of organizations forbidden in Austria," 82 but did not prohibit veterans from wearing World War II decorations not bearing the swastika - an incomplete victory at best for resistance fighters, racial or political victims of National Socialist policy, and left-wing politicians and pedagogues, for it did not censure those who endorsed or participated in Nazi militarism.

80. Bundesheer soldiers who participated in reunions, marches, or demonstrations did not initially or consistently comply with $\$ 36$ paragraphs 2 and 4 of the Wehrgesetz, which granted soldiers the full rights of nonuniformed citizens, but prevented them from participating in political activity in uniform. See ÖStA/AdR, BMLV 234.843-I/Präs/56, Vereine zur Pflege der militärischen Kameradschaft; Mitgliedschaft und Tragen der Uniform bei Veranstaltungen, 27 August 1956. Chancellory officials expressed greater concern that the Austrian soldiers might be brought into closer contact with "West German institutions," forbidden under $\$ 4$ of the State Treaty. Raab's staff seemed to indicate thereby that they were far less concerned with the enthusiasm for Soldatentreffen emanating from Austrians, and focused instead on the international legal ramifications of connections between veterans on both sides of the border; to direct attention to the former issues would have been to admit that certain residual pan-German, if not necessarily Nazi sentiment persisted in the Second Republic, in contradiction to his assertion that no affinity for closer connection with Germany existed in Austria. See ÖStA/AdR, BMLV 501.098-RB/55. BKA/ALV an das BMIGDÖS, 20 September 1955.

81. The ÖVP representative Alfons Gorbach expressed the opinion that because Austrians had always been valiant soldiers, they should be allowed to wear medals won during the Second World War, and if these decorations bore the swastika this was no longer a living symbol, but a reminder. He was not at all clear, however, as to what sort of reminder this would be, and did not recognize the inconsistency in wearing medals as a grim keepsake to celebrate the glory of fallen soldiers. Sten.Prot.NR,VIII. G.P., 15th Session, 6 December 1956, 512-23. This contradiction was pointed out by the SPÖ's Marie Emhart, ibid., 527-28.

82. BGBI. 1960/84, 611. 
Furthermore, the senior governing party remained divided over the significance of veterans' associations; indeed, the ÖVP Minister of Defense Graf, a former Third Reich military officer himself, denied consistently that the presence of federal troops as official honor guards at war monuments, soldiers' graves, or soldiers' cemeteries violated Bundesheer statutes. On the other hand, Soldatentreffen became politicized, left-wing critics contended, whenever individuals-especially prominent personalities such as Graf-blindly praised a tradition associated with oppressive regimes. ${ }^{83}$ Communists and Social Democrats, despite their bitter and fundamental programmatic differences, remained rather united in their rejection of both the conservative, Catholic character of the old monarchy and the militant nationalism and violent racial intolerance of National Socialism.

\section{Conclusion: Revisiting the Politics of Identity in Austrian Political Culture}

This essay has explored how veterans sought to reestablish an exclusive form of community on the basis of their shared frontline experience during the 1950s, and examined the sometimes conflicting reaction on the part of Austrian authorities concerned with preventing unrepentant veterans' groups from contradicting the myth of victimization upon which the Second Republic was founded. ${ }^{84}$ The goal of veterans' associations was to nurture the collective identity of those who had shared a transformative experience-not solely, or even primarily political lobbying for the establishment and maintenance of war-related disability or service pensions. ${ }^{85}$ Kameradschaftsbünde may not have been significant in terms of the size of the population they represented. Nonetheless, they offered a certain highly structured revivification of the existential bond between survivors, and commemoration of the connection between the living and the dead for those Austrians who relished camaraderie, sought to deny cul-

83. See for example the complaint forwarded to Raab by SPÖ deputies Rudolf Singer, Rudolf Appel, and Kurt Preussler regarding the presence of high-ranking, uniformed Bundesheer officers at a festival honoring the Austrian dead of both world wars at the Prandtauer-Kirche in St. Pölten, Lower Austria on 12 May 1957. Two uniformed Bundesheer soldiers also served as the honor guard. ÖStA/AR, BMLV 26.547-Wpol/57, 23 May 1957,3-4, as well Die Arbeiter-Zeitung, 25 May 1957. For Minister Graf's devensive response, see ÖStA/AdR-BMLV 26.547-Wpol/57, 24 May 1957, 5-6, as well as the following reports in ÖVP newspapers: "Eine überflüssige SPÖ-Anfrage. Keine Parteipolitik im Bundesheer," Kleines Volksblatt, 26 May 1957; "Heldenehrung ist keine Parteipolitik," Linzer Volksblatt, 27 May 1957.

84. Victor Turner reminds us that such examples of normative communitas are formed "under the influence of time, the need to mobilize and organize resources to keep the members of a group alive and thriving, and the necessity of social control among those members in pursuance of these and other collective goals..."Turner, Dramas, Fields, and Metaphors, 169.

85. Associations representing the interests of Austrian veterans who returned home between the late 1940s and 1955 from Soviet POW camps should not be confused with Kameradschaftsbünde in this respect, although Heimkehrer representation in veterans' associations was not entirely unusual. 
pability for war crimes, and resented the perceived humiliation of postwar occupation. While politicized right-wing Austrian and German Second World War veterans did not, as onetime, self-proclaimed neue Menschen, seek to destabilize society through acts of antisystemic violence-unlike their counterparts a generation earlier - the dislocation of their particular liminal experience imprinted itself deeply upon their postwar lives:

The soldier was a man who had lived for a seemingly endless period of time beyond civilian social categories, beyond any but purely formal and mechanical class distinctions. The experience of living outside of class, but in ranks, as socially declassified or not yet classified individuals, was productive of an undeniable sense of comradeship among those who shared this situation. But it was also productive of an inability to link up the social experience of war with the social problems and political issues of postwar society. ${ }^{86}$

Irrefutable military defeat and the Western Allies' decision to reconstruct German-speaking Central Europe after 1945, rather than to seek retribution as in 1918/19, preempted the kind of crisis resulting from the inability to reintegrate veterans that had plagued both German and Austrian societies during the interwar years. Western initiatives were influenced, of course, by perceptions of Cold War geopolitical exigencies, and facilitated by the integration of Western Germany and Austria, formally or de facto, into the Western community through generous Marshall Plan support. ${ }^{87}$

For Kameradschaftsbund members, however, the inability or unwillingness to acknowledge the highly-charged political symbolism of Soldatentreffen and to comprehend their wider social and political ramifications were reinforced by Western material assistance and the Westem-sponsored myth of Austrian victimization. Right-wing veterans could explain away the exceptional scale of violence on the eastern front, nourished by an atmosphere of unprecedented intolerant, racist nationalism, with language that resonated with elements of Nazi weltanschauung. The juxtaposition of Austrian particularism, expressed through the notion of victimization and internalization of the conviction that the Austrians, as a distinct part of a larger German Volksgemeinschaft, ${ }^{88}$ had sacrificed themselves for the preservation of the Western cultural inheritance against the hitherto "most sinister of Asiatic onslaughts" drew back the curtain somewhat, revealing the fragility of the Lebensluge. Insofar as organized, rightwing veterans persevered in their stubborn interpretation of the Cold War as a

86. Leed, No Man's Land, 200.

87. See, for example, Günter Bischof, “'Austria looks to the West': Kommunistische Putschgefahr, geheime Wiederbewaffnung und Westorientierung am Anfang der fünfziger Jahre" in Östereich in den Fünfzigern, ed. Thomas Albrich, Klaus Eisterer, Michael Gehler, and Rolf Steininger (Innsbruck, 1995), 183-209.

88. See the Herr Lang case study in Ziegler and Kannonier-Finster, Österreichs Gedächtnis, 173-92. 
continuation of the "noble struggle" against Bolshevism, however, the sanctity of the Frontkämpfer experience was preserved. ${ }^{89}$ Two sets of factors are important in this context. First, for Kameradschafisbündler the reenfranchisement of the Minderbelasteten in 1948/49, the Soviet Union's withdrawal from Austria in 1955, and the general amnesty for all Ehemaligen (former) National Socialists in 1961 represented decisive victories in an ultimately successful crusade. Second, the Moscow Declaration's pronouncement on Austrian victimization created an official, public memory of the wartime experience, which produced and perpetuated the private memory of individuals who could reflect upon their individual experience as one of victimization.

As the testimonial of representative Austrian veterans in the work of Meinrad Ziegler and Waltraud Kannonier-Finster attests (representative of all postwar political camps, and with divergent attitudes toward the Nazi regime prior to 1938), some Austrians were quite capable of reconstructing their individual experiences as Opfer, despite having participated in the war, and even having supported the Nazi regime. A great number had hoped for economic rejuvenation from the Anschluss in 1938, yet were disillusioned by the devastation and privation the war visited upon them; others felt victimized by a Nazi regime which, they contended, had betrayed the ideal of the Volksgemeinschaft it had promised by treating Austrians as second-class Germans. Others felt a certain compulsion to support the regime out of fear of the consequences. For some soldiers, victimization assumed the form of the execution of their professional duties in the face of real or imagined snubs or ridicule from their "Prussian" comrades-in-arms; for others, victimization entailed detention in prisoner of war camps. ${ }^{90}$

The volatile elements of the Austrian past, manifested in the embarrassment veterans' groups posed to the government, have been repressed, but clearly not resolved. The fallout from Kurt Waldheim's presidential election and Jörg Haider's guest appearances at Soldatentreffen suggests in no uncertain terms that the "grammar" of Austrian political culture-particularly the curious phenomenon of an untruth concerning victimization (or at best, a partial truth) serving as the "Magna Carta" of the Second Republic-have, to the present, not preserved foundational taboos from violation. It suggests that a substantial and vocal minority of young and old alike is unwilling to sustain the delicate psychic balance upon which the Lebenslüge rests, and has been prepared to seek alternatives to Social Democratic or Catholic conservative visions of the future under recent post-Cold War conditions of instability and uncertainty. As the last of the Kameradschaftsbündler pass away, the challenge that these new right-wing critics represent to the Second Republic's dominant political discourse reflects the lack

89. Gärtner and Rosenberger, Kriegerdenkmäler, 115.

90. Ziegler and Kannonier-Finster, Österreichs Gedächtnis, 87ff. 
of resolution in conflicting notions of Pflichterfullung vs. victimization in Austrian public and private memory, and the ambiguousness of Austria's relationship to Germany throughout the twentieth century. ${ }^{91}$

John Carroll University

91. Two examples illustrate this point. First, in reaction to the increased presence of "undesirable" foreigners from the eastern Mediterranean and southern or eastern Europe in Austria in the 1980 s and earty 1990s taking jobs and putting Austrians out of work, Haider presented a speech praising the "orderliness" and "efficiency" of Nazi Beschäftigungspolitik. His comments were received enthusiastically by most FPÖ supporters, but the embarrassment and consternation it provoked prompted Haider to step down from his position as provincial governor of Carinthia in June 1991, after a tenure of little more than two years. The foreign presence in Austria is less than 10 percent of the total population, and their employment is overwhelmingly in tasks and physical labor highly undesirable to most Austrian citizens. The second example pertains to the discovery of skeletal remains dated, initially, from the early-mid 1940s at a construction site in Lambach. Upper Austria in late January 1996. The find prompted the following remarks from some of the town's residents: "Where are the Jews in there, then?"; "Is it known for certain that those are Jews? Or are they our German soldiers?" Cited in "Lambacher Skelettfunde: 'Sans eh unsere deutschen Soldaten'?" Profil 6 (3 February 1996): 23. 